\title{
Inflasi Berdasarkan Pandangan M. Umer Chapra
}

\author{
Muhammad Ridha \\ Pascasarjana UIN Sumatera Utara Medan \\ tanyamuhammadridha@gmail.com \\ Muhammad Yafiz \\ Pascasarjana UIN Sumatera Utara Medan \\ muhammadyafiz@uinsu.ac.id
}

\begin{abstract}
According to Islamic economists, inflation has very bad effect on the economy because it disruptions of money function, weakens of saving's spirit, decreases the production of goods, and weakens of purchasing power. Inflation also attracted the attention of M. Umer Chapra as a Muslim economist. This study to analyze M. Umer Chapra's opinion on inflation. This research with qualitative approach of historical research, which examines history of the character which includes ideas, thoughts, and things that influence the formation of his thoughts. Data collection methods is using library research with the object about Chapra's thoughts relating to inflation, traced through his works. Chapra thought is a blend of traditional science, religion and modern economics. The results concluded that his thinking was dominated by macroeconomics because he was involved in the world economy, monetary policy, Islamic financial institutions which were more emphasized by the central bank, policies and inflation problems. Chapra's view of efforts to suppress inflation is the need for price stability and strategy. The disadvantage is that in a tolerant attitude towards western financial instruments, it must emphasize moral improvement for the course of fair economy as the solution to the failure of the capitalist and socialist economic systems.
\end{abstract}

Keywords: Monetary, Inflation, Umer Chapra

\begin{abstract}
Abstrak
Menurut para ekonom Islam, inflasi berakibat sangat buruk bagi perekonomian karena menimbulkan gangguan terhadap fungsi uang, melemahkan semangat menabung, turunnya produksi barang, dan daya beli masyarakat makin melemah. Inflasi ini juga menarik perhatian Umer Chapra sebagai salah seorang ekonom muslim. Penelitian ini bertujuan untuk menganalisis pendapat Chapra terhadap inflasi. Jenis penelitian dengan pendekatan kualitatif berbentuk
\end{abstract}


penelitian sejarah, yaitu meneliti sejarah terhadap kehidupan seorang tokoh meliputi ide, pemikiran, serta hal-hal yang berpengaruh dalam pembentukan pemikirannya. Metode pengumpulan data menggunakan data kepustakaan dengan objek penelitian adalah tentang pemikiran Chapra yang berkenaan dengan inflasi, yang ditelusuri melalui karya-karyanya. Pemikiran Chapra merupakan perpaduan antara ilmu tradisional, ilmu agama dan ilmu ekonomi modern. Hasil penelitian ini menyimpulkan bahwa pemikirannya didominasi oleh bidang perekonomian makro karena beliau banyak berkecimpung di dunia perekonomian negara, kebijakan moneter, lembaga keuangan syariah yang lebih ditekankan kepada bank sentral dan kebijakan-kebijakannya serta permasalahan inflasi. Pandangan Chapra tentang upaya menekan inflasi, yaitu harus adanya kestabilan harga dan strategi. Sedangkan kekurangannya terletak pada sikap toleran terhadap instrumeninstrumen keuangan barat, harus mengedepankan pentingnya perbaikan moral bagi jalannya perekonomian yang adil menjadi solusi bagi kegagalan sistem ekonomi kapitalis dan sosialis.

Kata kunci: Moneter, Inflasi, Umer Chapra.

\section{Pendahuluan}

Sistem ekonomi adalah satu kesatuan mekanisme dan lembaga pengambilan keputusan yang mengimplementasikan keputusan terhadap produksi, distribusi dan konsumsi dalam suatu daerah atau wilayah. Terdapat banyak faktor yang membentuk suatu sistem ekonomi, seperti ideologi, nilai-nilai yang dianut, kebudayaan, sistem politik, keadaan alam, sejarah, dan lain-lain. Pada umumnya, sistem ekonomi juga didasarkan pada pemikiran, konsep, atau teori-teori ekonomi tertentu yang diyakini kebenarannya. Menurut Gregory and Stuart, elemen kunci dari suatu sistem ekonomi adalah:

1. Hak kepemilikan

2. Mekanisme provisi informasi dan koordinasi dari keputusan-keputusan

3. Metode pengambilan keputusan

4. Sistem insentif bagi perilaku ekonomi, suatu sistem ekonomi kemungkinan memberikan tekanan pada jenis hak milik tertentu, namun secara umum dapat dikategorikan menjadi hak milik individu, hak milik sosial, dan hak milik negara. ${ }^{1}$ 
Suatu sistem ekonomi kemungkinan memiliki kebijakan tersendiri, termasuk kebijakan dalam menekan inflasi. Ekonomi konvensional mempunyai cara dalam mengatasi inflasi, demikian pula ekonomi Islam mempunyai cara, sistem, dan strategi tersendiri dalam mengatasi inflasi. Seperti diketahui bahwa inflasi merupakan fenomena ekonomi yang selalu menarik untuk dibahas terutama berkaitan dengan dampaknya yang luas terhadap makroekonomi agregat, pertumbuhan ekonomi, keseimbangan eksternal, daya saing, tingkat bunga, dan bahkan distribusi pendapatan. Inflasi juga berperan dalam mempengaruhi mobilisasi dana lewat lembaga keuangan formal.

Secara umum inflasi adalah kenaikan tingkat harga secara umum dari barang/komoditas dan jasa selama suatu periode waktu tertentu. Inflasi dapat dianggap sebagai fenomena moneter karena terjadinya penurunan nilai unit penghitungan moneter terhadap suatu komoditas. ${ }^{2}$ Menurut Sadono Sukirno, inflasi yaitu sebagai suatu proses kenaikan harga-harga yang berlaku dalam suatu perekonomian. ${ }^{3}$ Dengan kata lain, terlalu banyak uang yang memburu barang yang terlalu sedikit. Inflasi biasanya menunjuk pada harga-harga konsumen, tapi bisa juga menggunakan harga-harga lain (harga perdagangan besar, upah, harga, aset dan sebagainya).

Inflasi tidak terlalu berbahaya apabila bisa diprediksikan, karena setiap orang akan mempertimbangkan prospek harga yang lebih tinggi di masa yang akan datang dalam pengambilan keputusan. Pada kenyataannya, inflasi tidak bisa diprediksikan, berarti orang-orang seringkali dikagetkan dengan kenaikan harga. Hal ini mengurangi efisiensi ekonomi karena orang akan mengambil risiko yang lebih sedikit untuk meminimalkan peluang kerugian akibat kejutan harga. Semakin cepat kenaikan inflasi, semakin sulit untuk memprediksikan inflasi di masa yang akan datang. Kebanyakan ekonom berpendapat bahwa perekonomian akan berjalan efisien apabila inflasi rendah. Idealnya, kebijakan ekonomi makro harus bertujuan menstabilkan harga-harga. Sejumlah ekonom berpendapat bahwa tingkat inflasi yang rendah merupakan hal yang baik apabila itu terjadi akibat dari inovasi. Produk-produk baru yang diperkenalkan pada harga tinggi, akan jatuh dengan cepat karena persaingan. ${ }^{4}$

Penyebab inflasi adalah kenaikan harga-harga barang yang diimpor, penambahan penawaran uang yang berlebihan tanpa diikuti oleh pertambahan 
produksi dan penawaran barang, serta terjadinya kekacauan politik dan ekonomi sebagai akibat pemerintahan yang kurang bertanggung jawab. Adapun penyebab lain dari inflasi antara lain uang yang beredar lebih besar daripada jumlah barang yang beredar, sehingga permintaan akan barang mengalami kenaikan, maka dengan sendirinya produsen akan menaikkan harga barang dan apabila kondisi seperti ini dibiarkan maka akan terjadi inflasi. ${ }^{5}$

Menurut para ekonom Islam, inflasi berakibat sangat buruk bagi perekonomian karena:

1. Menimbulkan gangguan terhadap fungsi uang, terutama terhadap fungsi tabungan (nilai simpan), fungsi dari pembayaran di muka, dan fungsi dari unit penghitungan. Orang harus melepaskan diri dari uang dan aset keuangan akibat dari beban inflasi tersebut. Inflasi juga telah mengakibatkan terjadinya inflasi kembali, atau dengan kata lain selffeeding inflation

2. Melemahkan semangat menabung dan sikap terhadap menabung dari masyarakat (turunnya marginal propensity to save);

3. Meningkatkan kecenderungan untuk berbelanja terutama untuk non-primer dan barang-barang mewah (naiknya marginal propensity to consume)

4. Mengarahkan investasi pada hal-hal yang non-produktif yaitu penumpukan kekayaan (hoarding) seperti; tanah, bangunan, logam mulia, mata uang asing dengan mengorbankan investasi ke arah produktif seperti: pertanian, industrial, perdagangan, transportasi, dan lainnya. ${ }^{6}$

Taqiuddin Ahmad ibn al-Maqrizi (1364M - 1441M), yang merupakan ekonom muslim dan juga salah satu murid Ibnu Khaldun, menggolongkan inflasi dalam dua golongan yaitu inflasi akibat berkurangnya persediaan barang (Natural inflation) dan inflasi akibat kesalahan manusia (Human Error Inflation).

Selain Taqiuddin Ahmad ibn al-Maqrizi ekonom Islam modern yang produktif menulis dan menuangkan ide-ide tentang ekonomi Islam kedalam beberapa tulisan atau paper mengenai inflasi ialah M. Umer Chapra. Tulisantulisan Chapra menjadi salah satu pondasi intelektual dalam subjek ekonomi Islam dan pemikiran Ekonomi muslim modern. Buku pertamanya, "Towards a Just Monetary Sistem”, dianggap sebagai presentasi terbaik terhadap teori moneter Islam sampai saat ini. Terkait dengan pembahasan mengenai inflasi, Chapra beranggapan bahwasanya jurang pemisah antara ketersediaan sumber daya yang 
terbatas dan persediaan barang dan jasa yang belum dapat mengimbangi permintaan dapat menimbulkan ketegangan pada masyarakat modern. Jurang ini dapat mempercepat laju inflasi yang kini menjadi salah satu masalah utama yang dihadapai oleh ekonomi dunia.

Selain itu Chapra juga beranggapan bahwasanya dengan sumber daya yang tersedia, tidak mungkin untuk memenuhi permintaan barang dan jasa. Hasil yang jelas adalah kenaikan inflasi yang diikuti oleh resesi. Dengan tidak adanya transformasi moral dan perubahan dalam pemikiran ekonomi, upaya apapun oleh pemerintah baik negara demokrasi maupun sosialis tidak dapat menghadapi hal ini kecuali untuk periode yang singkat.

\section{Tinjauan Pustaka}

\section{Inflasi}

Inflasi diartikan sebagai kenaikan jumlah uang beredar atau kenaikan likuiditas dalam sebuah perekonomian. Pengertian tersebut mengacu pada gejala umum yang ditimbulkan oleh adanya kenaikan jumlah uang beredar di masyarakat yang diduga telah menyebabkan terjadinya kenaikan harga-harga. Dalam perkembangan lebih lanjut, inflasi dapat juga diartikan sebagai kenaikan terus menerus dalam tingkat harga suatu perekonomian akibat adanya kenaikan permintaan agregat atau penawaran agregat.

Dalam pengertian yang lain inflasi merupakan persentase kenaikan harga sejumlah barang dan jasa yang secara umum dikonsumsi rumah tangga. Ada barang atau jasa yang harganya naik atau ada barang atau jasa yang harganya turun, namun ada juga barang atau jasa yang harganya tetap. Sedangkan menurut Boediono dalam buku Ekonomi Moneter dan Kebanksentralan inflasi adalah kenaikan harga barang secara umum dan kenaikannya secara terus menerus. Defenisi ini sejalan dengan defenisi yang dikemukakan Suseno dan Siti Aisyah, inflasi secara singkat dapat didefenisikan sebagai kecenderungan menaiknya harga-harga barang dan jasa secara umum yang berlangsung secara terus-menerus.

\section{Jenis-Jenis Inflasi}

\section{Inflasi Karena Tarikan Permintaan (Demand Full Inflation)}

Yaitu kenaikan harga-harga yang terjadi akibat kenaikan permintaan agregat $(\mathrm{AD})$ yang lebih besar dari penawaran agregat (AS). Artinya inflasi terjadi 
apabila pendapatan nasional lebih besar dari pendapatan potensial. Inflasi karena tarikan permintaan bisa digambarkan dalam grafik berikut ${ }^{7}$ :

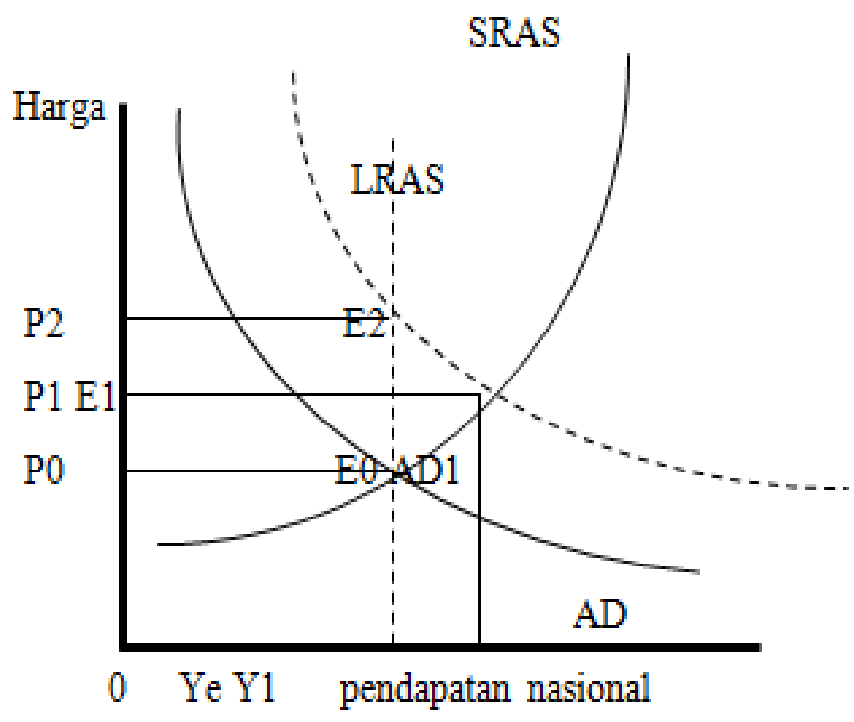

Gambar 1 Demad-Pull Inflation

Berdasarkan grafik diatas dapat diasusimkan bahwa permintaan agregat bertambah, sehingga kurva $\mathrm{AD}$ bergeser ke kanan menjadi AD1. Akibatnya tingkat harga dan output naik di sepanjang kurva SRAS, masing-masing dari P0 menjadi P1 dan dari Ye menjadi Y1. Dalam jangka panjang, pendapatan nasional akan kembali menuju tingkat keseimbangan yang menunjukkan full employment (Ye). Akibatnya tingkat harga naik menjadi P1 dan keseimbangan baru akan tercapai pada titik E2.

\section{Inflasi Karena Dorongan Biaya (Cost Push Inflation)}

yaitu inflasi yang disebabkan karena peningkatan harga-harga akibat naiknya biaya-biaya. Apabila permintaan terhadap bahan baku melebihi penawarannya, maka harga akan naik. Karena para pabrikan membayar lebih mahal atas bahan baku mereka menetapkan harga produk akhir yang lebih tinggi kepada pedagang dan pedagang menaikkan harga barang tersebut kemudian akan ditanggung oleh konsumen. 


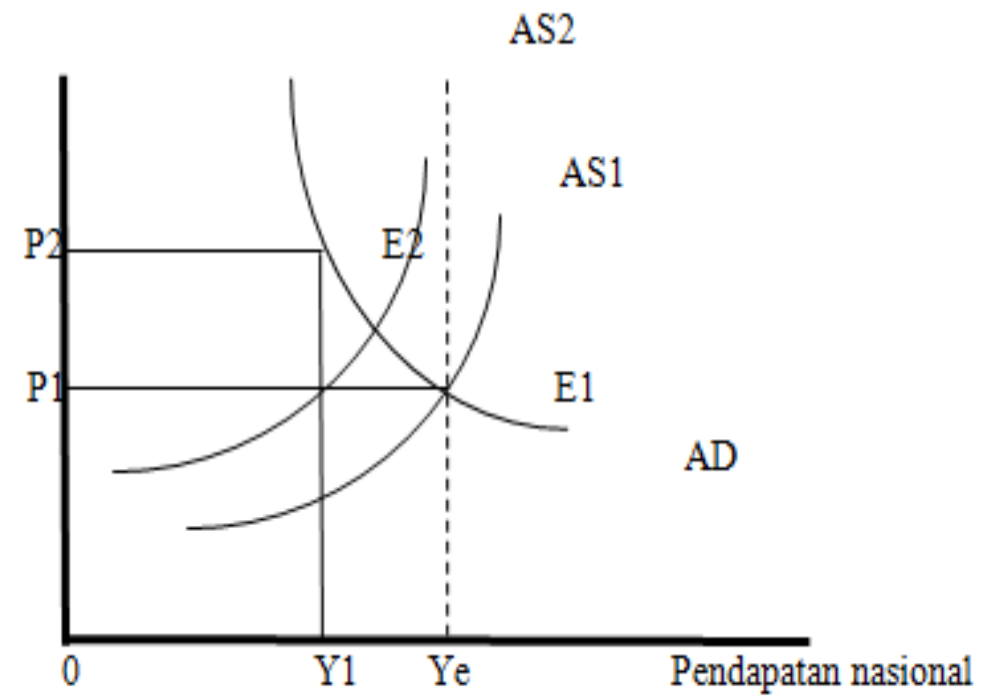

\section{Gambar 2 Cost-Push Inflation}

Berdasarkan grafik di atas dapat diasumsikan keseimbangan ekonomi mulamula terjadi pada titik E1 dengan permintaan agregat $\mathrm{AD}$ dan penawaran agregat AS1. Misalkan buruh menuntut kenaikan upah akibatnya kurva AS bergeser ke kiri dari AS1 menjadi AS2. Tingkat harga naik dari P1 menjadi P2 dan output turun dari Ye menjadi Y1 dengan keseimbangan baru tercapai pada titik E2.

\section{Inflasi karena ekpektasi}

Secara umum inflasi juga dapat dikelompokkan menurut jenisnya yang mencakup inflasi secara umum, inflasi berdasarkan asalnya, inflasi berdasarkan cakupan pengaruhnya, inflasi berdasarkan tingkat keparahannya, dan inflasi berdasarkan periode. ${ }^{8}$

\section{Dampak Inflasi Terhadap Perekonomian}

a. Menurunnya tingkat kesejahteraan masyarakat

b. Memperburuk distribusi pendapatan

\section{Kebijakan Moneter dan Fiskal dalam Mengatasi Inflasi}

Kebijakan moneter adalah kebijakan bank sentral atau otoritas moneter dalam bentuk pengendalian besaran moneter dan atau suku bunga untuk mencapai tujuan perekonomian yang diinginkan. ${ }^{9}$ Pada umumnya besaran moneter meliputi uang primer (M0), uang beredar dalam artian sempit (M1), dan uang beredar 
dalam artian luas (M2). Sementara itu tujuan kebijakan moneter meliputi terjaganya stabilitas ekonomi makro yang antara lain dicerminkan oleh stabilitas harga (rendahnya laju inflasi), membaiknya perkembangan output riil (pertumbuhan ekonomi), dan cukup luasnya lapangan/kesempatan kerja yang tersedia.

Untuk mencapai sasaran inflasi, kebijakan moneter dilakukan secara forward looking artinya perubahan stance kebijakan moneter dilakukan melalui evaluasi apakah perkembangan inflasi ke depan masih sesuai dengan sasaran inflasi yang telah dicanangkan. Dalam hal ini kebijakan moneter juga ditandai dengan transparansi dan akuntabilitas kebijakan kepada publik. Secara operasional, stance kebijakan moneter dicerminkan oleh penetapan suku bunga kebijakan (BI rate) yang diharapkan akan mempengaruhi suku bunga pasar uang, suku bunga deposito dan suku bunga kredit perbankan. Perubahan suku bunga ini pada akhirnya akan mempengaruhi output dan inflasi. Target atau sasaran inflasi merupakan tingkat inflasi yang harus dicapai oleh Bank Indonesia, berkoordinasi dengan Pemerintah. Penetapan sasaran inflasi berdasarkan UU mengenai Bank Indonesia dilakukan oleh Pemerintah. Dalam Nota Kesepahaman antara Pemerintah dan Bank Indonesia, sasaran inflasi ditetapkan untuk tiga tahun ke depan melalui Peraturan Menteri Keuangan (PMK). ${ }^{10}$

Kebijakan fiskal secara etimologi berasal dari dua kata, yaitu kebijakan dan fiskal. Kebijakan (policy) diberi arti yang bermacam-macam, Harold D. Laswell dan Abraham Kaplan memberi arti kebijakan sebagai suatu program pencapaian tujuan, nilai-nilai dan praktik-praktik yang terarah. ${ }^{11}$ Seorang ahli, James E. Anderson merumuskan kebijakan adalah sebagai perilaku dari sejumlah aktor (pejabat, kelompok, instansi pemerintah) atau serangkaianaktor dalam suatu bidang kegiatan tertentu. ${ }^{12}$ Fiskal yaitu 1) berhubungan dengan soal-soal finansial Fiskal yaitu 1) berhubungan dengan soal-soal finansial; 2) pada waktu ini istilah fiskal digunakan dalam arti khusus yang berlawanan dengan istilah "moneter". Fiskal berhubungan dengan "fisc" yaitu aspek finansial pemerintah, ${ }^{13}$ sedangkan fiscal policy (kebijakan fiskal) adalah suatu instrumen manajemen permintaan (demand management) yang berusaha mempengaruhi tingkat aktivitas ekonomi melalui pengendalian pajak (taxation) dan pengeluaran pemerintah (government expenditure). ${ }^{14}$ 
Secara terminologi, menurut Mustafa Edwin Nasution, et al., dalam ekonomi konvensional kebijakan fiskal dapat diartikan sebagai langkah pemerintah untuk membuat perubahan-perubahan dalam sistem pajak atau dalam pembelanjaan (dalam konsep makro disebut dengan government expenditure). ${ }^{15}$ Menurut Eko Suprayitno, kebijakan fiskal adalah kebijakan yang diambil pemerintah untuk membelanjakan pendapatannya dalam merealisasikan tujuantujuan ekonomi. ${ }^{16}$

\section{Inflasi dalam Perspektif Ekonomi Islam}

Dalam ekonomi Islam tidak mengenal inflasi, karena mata uang yang dipakai adalah dinar dan dirham, yang mana mempunyai alat nilai yang stabil dan dibenarkan oleh Islam. Akan tetap dinar dan dirham dalam artian sebenarnya yaitu yang dalam bentuk emas maupun perak bukan dinar-dirham yang sekadar nama. Adiwarman Karim mengatakan bahwa Syekh an-Nabhani memberikan beberapa alasan mengapa mata uang yang sesuai itu adalah dengan menggunakan emas. Ketika Islam melarang praktik penimbunan harta, Islam hanya mengkhususkan larangan tersebut untuk emas dan perak, padahal harta itu mencakup semua barang yang bisa di jadikan kekayaan.

Penurunan nilai dinar atau dirham memang masih mungkin terjadi, yaitu ketika nilai emas yang menopang nilai nominal dinar itu mengalami penurunan.Diantaranya akibat di ketemukannya emas dalam jumlah yang besar di suatunegara, tapi keadaan ini kecil sekali kemungkinannya. Atau kondisi terjadinya defisit anggaran pada pemerintahan Islam. Kondisi defisit anggaran pernah terjadi pada zaman Rasulullah dan ini hanya terjadi satu kali yaitu sebelum perang Hunain.

Menurut para ekonomi Islam, inflasi berakibat sangat buruk bagi perekonomian karena:

1. Menimbulkan gangguan terhadap fungsi uang, terutama terhadap fungsi tabungan (nilai simpan), fungsi dari pembayaran di muka, dan fungsi dari unit penghitungan. Orang harus melepaskan diri dari uang dan aset keuangan akibat dari beban inflasi tersebut. Inflasi juga telah mengakibatkan terjadinya inflasi kembali, atau dengan kata lain "selffeeding inflation" 
2. Melemahkan semangat menabung dan sikap terhadap menabung dari masyarakat (turunnya marginal propensity to save) Hal ini berakibat pada menurunnya dana pembiayaan yang akan di salurkan.

3. Meningkatkan kecenderungan untuk berbelanja terutama pembelanjaan untuk berang-barang non-primer dan barang-barang mewah (naiknya marginal propensity to consume)

4. Mengarahkan investasi pada hal-hal yang non-produktif yaitu penumpukan kekayaan (hoarding) seperti pada aset property yaitu tanah dan bangunan, logam mulia, mata uang asing dengan mengorbankan investasi ke arah produktif seperti pertanian, industrial, perdagangan, transportasi, dan lainnya. ${ }^{17}$

\section{Kebijakan Ekonomi Islam dalam Inflasi}

\section{Kebijakan Fiskal}

Dalam pemikiran Islam menurut An-Nabahan pemerintah merupakan lembaga formal yang mewujudkan dan memberikan pelayanan terbaik kepada rakyatnya. Pemerintah mempunyai kewajiban untuk mewujudkan kesejahteraan masyarakat, salah satunya yaitu tanggung jawab terhadap perekonomian diantaranya mengawasi faktor utama penggerak perekonomian. ${ }^{18}$

Majid mengatakan bahwa untuk mewujudkan masyarakat yang sejahtera, pemerintah Islam menggunakan dua kebijakan, yaitu kebijakan fiskal da nkebijakan moneter. Kebijakan tersebut telah dipraktikkan sejak zaman Rasullulahdan Khulafaur Rosyidin kemudian dikembangkan oleh para ulama. Tujuan dari kebijakan fiskal dalam Islam adalah untuk menciptakan stabilitas ekonomi, tingkat pertumbuhan ekonomi yang tinggi dan pemerataan pendapatan, ditambah tujuan lain yang terkandung dalam aturan Islam. ${ }^{19}$

Dalam mencapai tujuan pembangunan ekonomi ada beberapa instrumen yang bisa digunakan, yaitu :

a. Memaksimalkan penghimpunan zakat serta pengoptimalan pemanfaatan zakat. Pemaksimalan penghimpunan zakat dapat dimanfaatkan untuk berbagai macam kegiatan yang bertujuan dalam menjamin stabilitas ekonomi. Hal ini ditempuh apabila diasumsikan suatu perekonomian dalam kondisi full employment maka kenaikan permintaan agregat tidak akan menimbulkan kenaikan pada pendapatan riil nasional. 
b. Mengenakan biaya atas dana yang menganggur (cost of idle fund), hal ini agar mendorong masyarakat untuk menginvestasikan dananya tidak hanya melalui tabungan dan deposito tetapi diarahkan pada penciptaan pertumbuhan sektor riil. Dengan adanya biaya, maka setiap masyarakat dituntut untuk menginvestasikan dana yang mereka miliki tersebut.

c. Menggunakan prinsip bagi hasil pada setiap transaksi atau segala jenis usaha dan meninggalkan bunga. Pada sistem bagi hasil segala pihak yang terlibat akan membagi keuntungan dan kerugian bersama sesuai proporsi modalnya masing-masing, dengan demikian segala bentuk transaksi baik itu sektor rumah tangga, swasta maupun pemerintah semua dapat menjalankan prinsip bagi hasil tanpa menggunakan bunga.

\section{Kebijakan Moneter $^{20}$}

Pada zaman Rasulullah dan Khulafaur Rosyidin kebijakan moneter dilaksanakan tanpa menggunakan instrumen bunga sama sekali. Dalam perekonomian kapitalis tingkat bunga seringkali berfluktuasi, yang sengaja hanya disimpan pun akan terus menerus berubah. Penghapusan bunga dan kewajibanmembayar zakat sebesar $2.5 \%$ per tahun tidak hanya dapat meminimalisasi permintaan spekulatif akan uang maupun penyimpanan uang yang diakibatkanoleh tingkat bunga, melainkan juga memberikan stabilitas yang lebih tinggiterhadap permintaan uang. Preferensi likuiditas yang muncul dari motif spekulasi oleh karenanya tidak penting dalam perekonomian Islam. Variabel yang harus diformulasikan dalam kerangka kebijakan moneter Islam adalah stok uang, bukan tingkat suku bunga bank. Dalam sistem ekonomi Islam, bank sentral harus mengarahkan kebijakan moneternya untuk membiayai pertumbuhan potensial dalam output jangka menengah dan jangka panjang demi mencapai harga yang stabil dan tujuan-tujuan sosiosekonomi Islam.

Dalam perkonomian Islam, untuk menjaga stabilitas tingkat harga ada beberapa hal yang dilarang, yaitu :

a. Permintaan yang tidak riil. Permintaan uang hanya untuk keperluan transaksi dan berjaga-jaga

b. Penimbunan mata uang 
c. Transaksi tallaqi rukban. Yaitu mencegat penjual dari kampung atau daerah pinggiran di luar kota untuk dijual kembali di pusat kota demi mendapatkan keuntungan dari ketidakpastian harga.

d. Transaksi kali bi kali. Yaitu transaksi tidak tunai, transaksi tunai diperbolehkan namun transaksi future tanpa ada barangnya adalah dilarang.

e. Segala bentuk riba.

Dalam kerangka strategi mekanik bagi kebijakan moneter, menurut Chapra yang tidak hanya membantu pengaturan penawaran uang sesuai dengan permintaan riil tetapi juga membantu memenuhi kebutuhan untuk menutup defisit asli pemerintah dan juga sekaligus mencapai tujuan-tujuan lain masyarakat Islam. Mekanik tersebut harus mencakup beberapa elemen, diantaranya: ${ }^{21}$

a. Target pertumbuhan pada M dan M0 Secara berkala bank sentral harus menetapkan pertumbuhan penawaran uang (M) sesuai dengan sasaran ekonomi nasional, termasuk pertumbuhan ekonomi yang dapat dipertahankan dan stabillitas dalam nilai uang.

b. Public share of demand deposit. Dalam jumlah tertentu (kondisi normal) demand deposit bank-bank komersil maksimum sampai 25\% harus diserahkan kepada pemerintah untuk membiayai proyek-proyek yang secara sosial menguntungkan.

c. Statutory reserve requirement. Bank-bank komersil harus memiliki cadangan dalam jumlah tertentu yaitu 10\%-20\% dari demand deposit mereka dengan bank sentral. Begitu pula sebaliknya dengan bank sentral. Statutory reserve requirement membantu memberikan jaminan atas deposit juga sekaligus membantu penyediaan likuiditas yang memadai bagi bank.

\section{Metode Penelitian}

\section{Jenis Penelitian}

Penelitian ini berbentuk penelitian sejarah tokoh, yaitu penelitian sejarah terhadap salah satu kehidupan seorang tokoh yang meliputi ide, pemikiran, serta hal-hal yang berpengaruh dalam pembentukan pemikirannya. Penelitianini merupakan penelitian kepustakaan (Library Research) dengan objek penelitian adalah Chapra tentang pemikirannya yang berkenaan dengan inflasi, yang ditelusuri melalui karya-karyanya langsung. Selain itu penelusuran juga dilakukan melalui bahan-bahan yang ditulis penulis-penulis lainnya dan para tokoh yang 
mendukung pemikiran Chapra. Jadi, motode penelitian ini bersifat menjelajah (Eksploratif) yang nantinya akan dianalisa pada setiap peristiwa yang terjadi.

Dilihat dari segi relevansinya dengan masyarakat, studi tokoh ini mempunyai pengaruh yang signifikan dalam aktivitas kehidupan masyarakat. Oleh karena itu, studi tokoh ini kemudian dikembangkan secara lebih luas di perguruan tinggi. ${ }^{22}$

Penelitian ini bertujuan mengembangkan konsep, menerangkan realitis yang berkaitan dengan penulusuran teori, serta mengembangkan pemahaman akan satu atau lebih dari fenomena yang dihadapi. ${ }^{23}$ Data-data dan informasi yang diperoleh dari kajian pustaka, dideskripsikan secara induktif sehingga menghasilkan formulasi nilai-nilai yang dapat dijadikan dasar etika bisnis. Pemikiran-pemikiran Chapra yang tertuang dalam karya-karyanya dirumuskan untuk membuat konstruk pemikiran inflasi Chapra secara utuh dan sistematis.

\section{Metode Pengumpulan Data}

Teknik yang digunakan pada pengumpulan data adalah studi dokumentasi yaitu teknik pengumpulan data yang tidak langsung ditujukan kepada subjek penelitian. Dokumen yabg diteliti dapat berupa berbagai macam bentuk, dan mencakup dokumen tidak resmi. Data-data ini diklasifikasikan menjadi data primer dan data sekunder. ${ }^{24}$

Penelitian ini menggunakan empat metode analisis, yaitu :

1) Induksi dan Deduksi

Induksi secara umum diartikan sebagai generalisasi. Kasus dan unsur pemikiran tokoh dianalisis, kemudian pemahaman yang ditemukan di dalamnya dirumuskan dalam pernyataan umum. Sedangkan deduksi dipahami sebagai uapaya eksplisitasi dan penerapan pikiran-pikiran seorang tokoh yang bersifat umum

2) Koherensi Intern

Agar pemikiran tokoh dapat dipahami secara tepat, maka seluruh konsep dan aspek-aspek pemikirannya dilihat menurut keselarasannya satu dengan yang lain. Selain itu ditetapkan pula inti pikirannya yang paling mendasar dan topik-topik yang paling sentral.

3) Holistika 
Pikiran seorang tokoh tidak dilihat secara atomistic, baik antara aspek pemikirannya maupun dalam interaksinya dengan seluruh kenyataan yang mengitarinya. Dengan demikian holistika (pandangan menyeluruh) dapat juga disebut sebagai totalisasi: semua di pandang dalam kesinambungannya dengan satu totalitas

4) Kesinambungan Historis

Dalam melakukan analisis dilihat benang merah yang menghubungkan pemikiran-pemikirannya baik lingkungan historis dan pengaruh yang dialaminya maupun perjalanan hidupnya sendiri. ${ }^{25}$

Menurut Nazir mengumpulkan data dalam penelitan sejarah disebut holistik yaitu memahami konsep tokoh yang bersangkutan dengan betul-betul melihat dalam rangkaian keseluruhan kisinya mengenai materi yang dibicarakan. Untuk itu yang menjadi sumber primer dalam literatur yang memuat pemikiran Chapra tentang inflasi adalah Economists Advisory Group Bussiness Research Study dan Toward a Just Monetary System. Sebagai data sekunder untuk mempertajam dan memperkaya informasi digunakan literatur atau karya-karya tokoh lain yang memuat dan berkenaan dengan pembahasan dalam penelitan ini.

Data Sekunder adalah data pendukung yang mendukung data primer, yang dalam hal ini yaitu beberapa kitab atau buku yang relevan dengan judul tulisan ini, di antaranya: Imamudin Yuliadi, Ekonomi Islam; Muslimin H. Kara, Bank Syariah Di Indonesia Analisis Terhadap Pemerintah Indonesia Terhadap Perbankan Syariah; Mahmud Muhammad Bablily, Etika Bisnis: Studi Kajian Konsep Perekonomian Menurut al-Qur'an dan as-Sunnah; Adiwarman Karim, Ekonomi Makro Islami; Zainul Arifin, Dasar-Dasar Manajemen Bank Syari'ah; Eko Suprayitno, Ekonomi Islam, Pendekatan Ekonomi Makro Islam dan Konvensional; Achmad Ramzy Tadjoedin, dkk, Berbagai Aspek Ekonomi Islam; Mustafa Edwin Nasution dkk, Pengenalan Eksklusif Ekonomi Islam; Nurul Huda dkk, Ekonomi Makro Islam; Afzalur Rahman, Doktrin Ekonomi Islam.

\section{Analisis Data}

Dalam menganalisa data terhadap penelitan sejarah sangat dibutuhkan interpretasi untuk menganalisa setiap peristiwa, jadi digunakan analisis isi 
(content analysis) yang didefinisikan oleh Abdurrahman dengan metodologi penelitian yang memanfaatkan seperangkat prosedur untuk menarik kesimpulan yang shahih dari sebuah buku atau dokumen.

\section{Hasil Penelitian}

\section{Biografi M. Umer Chapra}

M. Umer Chapra lahir pada tangal 1 Februari 1933 di Pakistan. Berkebangsaan Pakistan kemudian menetap di Saudi. ${ }^{26}$ Ayahnya bernama Abdul Karim Chapra. Chapra dilahirkan dalam keluarga yang taat beragama, sehingga ia tumbuh menjadi sosok yang mempunyai karakter yang baik. Keluarganya termasuk orang yang berkecukupan yang memungkinkan ia mendapatkan pendidikan yang baik pula. Masa kecilnya ia habiskan ditanah kelahirannya hingga berumur 15 tahun. Kemudian ia pindah ke Karachi untuk meneruskan pendidikannya disana sampai meraih gelar Ph.D dari Universitas Minnesota. Dalam umurnya yang ke 29, ia mengakhiri masa lajangnya dengan menikahi Khoirunnisa Jamal Mundi pada tahun 1962.

Chapra sangat berperan dalam perkembangan ekonomi Islam ide-ide cemerlangnya banyak tertuang dalam karangan-karangannya. Kemudian karena pengabdiannya ini beliau mendapatkan penghargaan dari Islamic Development Bank dan dari King Faisal International Award. Kedua penghargaan ini diperoleh pada tahun $1989 .{ }^{27}$

\section{Karya dan Pemikiran M. Umer Chapra}

M. Umer Chapra telah menulis 12 buku, 60 karya ilmiah dan 9 resensi buku, belum artikel lepas di berbagai jurnal dan media massa. Buku dan karya ilmiahnya banyak diterjemahkan dalam berbagai bahasa termasuk juga bahasa Indonesia . Buku Chapra yang membahas tentang moneter adalah, "Towards a Just Monetary Sistem”, Buku ini berusaha menjawab dan menganalisis berbagaimasalah yang berkaitan dengan sistem perbankan dan keuangan Islam.

Melalui penelitian yang dilakukan Chapra juga menuangkannya dalam buku yang berjudul Islam dan Tantangan Ekonomi. Dalam penelitian tersebut, ia mengkaji tiga sistem ekonomi Barat yaitu Kapitalisme, Sosialisme, dan gabungan dari dua sistem tersebut yaitu "negara kesejahteraan". Ia mengemukakan neraca ketiga sistem tersebut dari segi prestasi-prestasinya maupun kegagalan- 
kegagalannya. ${ }^{28}$ Ia mengemukakan bahwa buku ini merupakan suatu upaya menjawab pertanyaan-pertanyaan ${ }^{29}$ tentang apa, bagaimana, dan untuk siapa melakukan produksi. Berapa jumlah barang dan jasa yang harus diproduksi, siapa yang akan memproduksinya, dan dengan kombinasi sumber-sumber daya apa saja dan dengan teknologi yang bagaimana serta siapakah yang akan menikmati barang dan jasa yang diproduksi itu. ${ }^{30}$

Jawaban-jawaban pertanyaan tersebut menentukan alokasi sumber daya dalam ekonomi, distribusi antar individu dan antar konsumsi sekarang dan masa depan (tabungan dan investasi). ${ }^{31}$

\section{Pendapat M. Umer Chapra Tentang Inflasi}

Menurut Chapra, stabilitas dalam nilai uang tidak bisa dilepaskan dari tujuan dalam kerangka referensi yang Islami karena hal ini ditekankan Islam secara jelas mengenai ketulusan dan keterbukaan dalam berhubungan dengan semua manusia. ${ }^{32} \mathrm{Al}$ Qur'an dengan tegas menekankan perlunya ketulusan dan keadilan dalam nilai semua ukuran: "Dan berikanlah ukuran yang penuh dan timbangan dengan adil”. (QS. Al An'aam : 152). ${ }^{33}$

Menurut Chapra, inflasi mempunyai pengertian bahwa uang tidak dapat digunakan sebagai nilai tukar yang adil dan jujur. Ini menjadikan uang sebagai alat pembayaran yang tidak adil bagi penangguhan pembayaran dan penyimpanan nilai yang tidak dapat dipercaya. Uang dapat membuat sebagian orang menjadi tidak jujur kepada orang lain, bahkan meskipun tanpa disadari, dengan diam-diam merusak daya beli aset moneter.

Inflasi adalah simptom (gejala) dari ketidakseimbangan dan tidak cocok dengan penekanan Islam pada keseimbangan dan ekuilibrium. Menerima saja inflasi sama dengan menerima penyakit dan membiarkan hilangnya kemampuan perekonomian untuk bergerak secara reflek. Negara-negara yang mempunyai kemampuan besar untuk mengatasi tekanan-tekanan inflasi adalah yang paling berhasil dalam mencapai dan memelihara tingkat pertumbuhan ekonomi dan employment (tenaga kerja) yang lebih tinggi.

Inflasi di negara miskin ataupun kaya mempunyai konsekuensi yang sama dalam membuat distorsi (penyimpangan) output (hasil), meremehkan efisiensi dan investasi yang produktif dan dalam mendorong ketidakadilan dan ketegangan 
sosial. Satu-satunya cara untuk mengakhiri inflasi hanyalah menanggulangi akar sebab-sebabnya. ${ }^{34}$

Menurut Chapra, inflasi telah merebak, namun pada mulanya hal ini juga dijustifikasi. Kurva Phillips telah menyediakan rasionalitas yang diperlukan bagi para pembuat kebijakan dalam bentuk hubungan negatif antara inflasi di satu pihak dan pertumbuhan yang lebih tinggi serta kesempatan kerja di pihak yang lain. Mayoritas ekonom Keynesian kurang prihatin pada inflasi dan mereka tetap menggalakkan kebijakan-kebijakan ekspansioner selama periode pasca-Perang Dunia Kedua. Prof Henry Bruton, dalam rangkaian ceramahnya yang disampaikan di Universitas Bombay pada tahun 1961 menyatakan bahwa "kita dapat membuat inflasi menjadi suatu instrumen kebijakan dan bukannya mengontrol inflasi sebagai tujuan kebijakan". Tentu saja peringatan-peringatan diarahkan kepada mismanagement moneter dengan menyatakan bahwa "terlalu banyak mencetak uang hanya akan menimbulkan bahaya". ${ }^{35}$

Terkait kebijakan moneter dan fiskal Chapra menjelaskan bahwa Untuk menjamin pertumbuhan moneter "mencukupi" dan tidak "berlebihan", perlu memonitor secara hati-hati tiga sumber utama ekspansi moneter. Dua di antaranya adalah domestik. Pertama, membiayai defisit anggaran pemerintah dengan meminjam dari bank sentral. Kedua, ekspansi deposito melalui penciptaan kredit pada bank-bank komersial. Ketiga, bersifat eksternal, yaitu menguangkan surplus neraca pembayaran luar negeri. ${ }^{36}$

Gagasan Chapra tentang kebijakan moneter ia tuangkan dalam penjelasan yang cukup jelas. Ia mengatakan bahwa untuk menciptakan iklim pertumbuhan moneter yang memadai dalam arti mencukupi, dan tidak "berlebihan", perlu memonitor secara hati-hati tiga sumbser utama ekspansi moneter, yaitu defisit fiskal, penciptaan kredit bank komersial deposito, dan surplus neraca pembayaran.

\section{Strategi Untuk Menekan Inflasi Menurut M. Umer Chapra}

1. Perbaikan Moral (Bukan Hanya Dimensi Material Tetapi Juga Spiritual)

Chapra mengatakan bahwa "Elemen paling penting dari strategi Islam untuk merealisasikan tujuan-tujuan Islam adalah bersatunya semua hal yang dianggap sebagai aspek kehidupan biasa dengan spirit untuk meningkatkan moral manusia dan masyarakat tempat dia hidup. Tanpa peningkatan spirit semacam itu, tidak akan ada satu tujuan pun yang dapat direalisasikan dan kesejahteraan 
manusia yang sesungguhnya jadi sulit diwujudkan". ${ }^{37}$ Dalam perspektif Chapra bahwa elemen paling penting dari strategi Islam untuk merealisasikan tujuantujuan Islam adalah bersatunya semua hal yang dianggap sebagai aspek kehidupan biasa dengan spirit untuk meningkatkan moralmanusia dan masyarakat tempat dia hidup. Hal ini membawa pada inti konsepkesejahteraan dalamIslam.Kesejahteraan manusia hanyadapat diwujudkan melalui pemenuhan kebutuhan material dan spiritual manusia".

\section{Distribusi Pendapatan Dan Kekayaan Yang Merata}

Chapra mengatakan bahwa "Dengan demikian isi kedua yang penting dari strategi yang Islam adalah bahwa Islam telah memberikan satu cetak biru untuk pengorganisasian seluruh aspek kehidupan, ekonomi, sosial atau politik, yang memperkuat keberanian masyarakat untuk mengatakan yang benar dan mengaktualisasikan tujuan-tujuan yang sangat dekat dengan Islam. Misalnya, distribusi pendapatan dan kekayaan yang merata, tujuan-tujuan yang ingin dicapai oleh semua sistem ekonomi, tidak akan bisa dicapai tanpa: (a) keyakinan mengenai persaudaraan manusia yang hanya bermakna bagi mereka yang percaya akan Tuhan yang Esa yang menciptakan semua umat manusia, yang di hadapanNya semua manusia sama dan akar; dimintai pertanggungjawaban; (b) sistem sosio-ekonomi yang tidak menciptakan sikap sosial berdasarkan hukum survival Darwin, melainkan mereorganisasikan masyarakat atas landasan moral untuk mendorong interaksi sosio-ekonomi atas dasar keadilan dan kerjasama; (c) sistem sosial-politik yang mampu mencegah perlakuan tidak adil dan eksploitatif melalui berbagai cara, termasuk mencegah riba, dan memberikan dukungan material bagi yang lemah, masyarakat dan negara. Dengan berkembangnya diskusi dalam buku ini, semakin jelas kiranya bagaimana Islam meyakinkan realisasi tujuantujuannya". ${ }^{38}$ Untuk menjawab masalah ini, Islam telah menganjurkan untuk mengerjakan zakat, infaq dan shadaqoh. Kemudian Baitul Mal membagikan kepada orang yang membutuhkan untuk meringankan masalah hidup orang lain dengan cara memberi bantuan langsung ataupun tidak langsung.

\section{Penghapusan Riba}

Chapra mengatakan bahwa "Di antara elemen utama dari strategi bagi pembaharuan sistem keuangan dan perbankan (misalnya, penghapusan riba dan 
berbagi untung dan rugi) telah dituturkan oleh Al Qur'an dan Sunnah. Elemenelemen lain, tentu, harus dirancang oleh masyarakat Islam tergantung dari kondisi dan posisi relatif mereka dalam rangka mengaktualisasikan tujuan. Bagian-bagian strategi yang disarankan oleh Al Qur'an dan Sunnah tidak dapat ditawar-tawar lagi. Meskipun demikian, pengujian atas elemen-elemen lain akan berupa dukungan yang mereka berikan terhadap keseluruhan strategi syari'ah dan sumbangan yang mereka berikan untuk merealisasikan tujuan. Semakin kuat dukungan yang diberikan dan semakin besar sumbangan yang diberikan untuk mencapai tujuan akhir, semakin dikehendaki pula elemen-elemen strategi yang diberikan oleh manusia dengan catatan bahwa hal itu semua tidak bertentangan dengan syari'ah. Elemen-elemen yang terakhir ini, sudah barang tentu, tidak dapat sekali jadi, melainkan perlu diperbaiki dan disempurnakan secara berkelanjutan melalui suatu proses evolusi", ${ }^{39}$

\section{Kesimpulan}

Setelah mempelajari uraian dari bab-bab sebelumnya, maka dapat diambil kesimpulan bahwa pendapat M. Umer Chapra tentang upaya menekan inflasi yaitu harus ada stabilitas harga dan strategi. Stabilitas dalam nilai uang tidak bisa dilepaskan dari tujuan dalam kerangka referensi yang Islami karena hal ini ditekankan Islam secara jelas mengenai ketulusan dan keterbukaan dalam berhubungan dengan semua manusia. Al Qur'an dengan tegas menekankan perlunya ketulusan dan keadilan dalam nilai semua ukuran.

Hal ini sebagaimana dikemukakan Chapra: "Alternatif kebijaksanaan yang paling baik dan sesuai dengan norma keadilan sosio-ekonomi yang ditekankan oleh syari'ah adalah stabilitas harga. Menurut Chapra, strategi untuk menekan inflasi yaitu pertama, perbaikan moral (yang dikejar bukan hanya dimensi material tapi juga spiritual). Kedua, distribusi pendapatan dan kekayaan yang merata. Ketiga, penghapusan riba. Menurut Chapra, inflasi mempunyai pengertian bahwa uang tidak dapat digunakan sebagai nilai tukar yang adil dan jujur. Ini menjadikan uang sebagai alat pembayaran yang tidak adil bagi penangguhan pembayaran dan penyimpanan nilai yang tidak dapat dipercaya. Uang dapat membuat sebagian orang menjadi tidak jujur kepada orang lain, bahkan meskipun tanpa disadari, dengan diam-diam merusak daya beli aset moneter. 


\section{Catatan}

${ }^{1}$ Pusat Pengkajian dan Pengembangan Ekonomi Islam (P3EI), Ekonomi Islam, (Jakarta: Raja Grafindo Persada, 2011), h. 74

${ }^{2}$ Adiwarman Karim, Ekonomi Makro Islam, (Jakarta: Raja Grafindo Persada, 2007), h. 135.

${ }^{3}$ Sadono Sukirno, Pengantar Teori Makro Ekonomi, (Jakarta: Raja Grafindo Persada, 2010), h. 15 .

${ }^{4}$ Nurul Huda, et al., Ekonomi Makro Islam, (Jakarta: Kencana, 2008), h. 176.

${ }^{5}$ Sadono Sukirno, Pengantar Teori Makro Ekonomi, h. 15.

${ }^{6}$ Adiwarman Karim, Ekonomi Makro Islam, h. 139.

${ }^{7}$ Nurul Huda, et al., Ekonomi Makro Islam, (Jakarta: Kencana, 2008)

${ }^{8}$ M. Natsir, Ekonomi Moneter dan Kebanksentralan, (Jakarta : Mitra Wacana Media, 2014), h. 261 .

9 Iskandar Simorangkir, Pengantar Kebanksentralan : teori dan praktik di Indonesia, (Jakarta : Rajawali Pers, 2014), h. 61.

${ }^{10}$ http://www.bi.go.id/id/moneter/inflasi/bi-dan-inflasi/Contents/Penetapan, diakses tanggal 20 September 2018

11 M. Irfan Islamy, Prinsip-prinsip Perumusan Kebijaksanaan Negara, Jakarta: Bumi Aksara, 2003, h. 15-16.

12 Solichin Abdul Wahab, Analisis Kebijaksanaan dari Reformulasi ke ImplementasiKebijaksanaan Negara, Jakarta: Bumi Aksara, 2005, h. 2.

${ }^{13}$ Winardi, Kamus Ekonomi (Inggris - Indonesia), Bandung: Alumni, 2005, h. 210.

${ }^{14}$ Collins, Kamus Lengkap Ekonomi, terj. Tumpul Rumapea dan Posman Haloho, Jakarta: Airlangga, 1994, h. 232.

${ }^{15}$ Mustafa Edwin Nasution, et al., Pengenalan Eksklusif Ekonomi Islam, Jakarta: kencana, 2006, h. 203.

${ }^{16}$ Eko Suprayitno, Ekonomi Islam Pendekatan Ekonomi Makro Islsam dan Konvensional, Yogyakarta: Graha Ilmu, 2005, h. 159

${ }^{17}$ Rafiq al-Masri, a paper submitted in the Second Workshopon Inflation: Inflation and Its Impacton Societies -The Islamic Solution; Kuala Lumpur 1996.

18 M. Faruq An-Nababan, Sistem Ekonomi Islam: Pilihan Setelah Kegagalan Sistem Kapitalis dan Sosialis, (Yogyakarta: UII Pers, 2000), h. 59

${ }^{19}$ Majid M Nazori, Pemikiran Ekonomi Islam Abu Yusuf Relevasinya dengan Ekonomi Kekinian, (Yogyakarta: Pusat Studi Ekonomi Islam (PSEI) Sekolah Tinggi Ilmu Syariah, 2003), h. 221-223

${ }^{20}$ Nurul Huda, dkk, Ekonomi Makro Islam, h. 193-195

${ }^{21}$ Umer M Chapra, Al-Qur'an Menuju Sistem Moneter yang Adil (terj), (Yogyakarta: Dana Bhakti Prima Yasa, 1997), h. 173-176 
22 Arief Furchan dan Agus Maimun, Study Tokoh: Metode Penelitian Mengenai Tokoh (Yogyakarta: Pustaka Pelajar, 2005), h. 6

${ }^{23}$ Lexy J. Moleong, Metodologi Peneitian Kualitatif, (Bandung: Remaja Rosdakarya, 2000), h. 4

${ }^{24}$ M. Arif Mufraini, Metodologi Penelitian Bidang Studi Ekonomi Islam, (Jakarta: UIN Jakarta Press, 2013), h. 45

${ }^{25}$ Azhari Akmal Tarigan \& dkk, Metodologi Penelitian Ekonomi Islam, (Medan: La-Tansa Press, 2011), h. 127-129

${ }^{26}$ M. Umer Chapra, Reformasi Ekonomi Sebuah Solusi Perspektif Islam, terj. Ikhwan Abidin Basri, MA (Jakarta: Bumi Aksara, 2008), h.vii

${ }^{27}$ http://id.wikipedia.org/wiki/M._Umer_Chapra"diakses 27 Januari 2018

${ }^{28}$ Ibid.,

${ }^{29}$ Ibid., h. 4

${ }^{30}$ Ibid., h. 10

${ }^{31}$ Ibid., h. 11

${ }^{32}$ M. Umer Chapra, Al-Qur'an Menuju Sistem Moneter Yang Adil, Terj. Lukman Hakim, Yogyakarta: Dana Bhakti Prima Yasa, 1997, h. 6.

${ }^{33}$ Yayasan Penyelenggara Penterjemah/Pentafsir al-Qur'an, Al-Qur'an dan Terjemahnya, Departemen Agama Jakarta, 1986, h. 278.

${ }^{34}$ Ibid.,

${ }^{35}$ M. Umer Chapra, Islam dan Pembangunan Ekonomi, terj. Ikhwan Abidin, Jakarta: Gema Insani Press, 2000, h. 48.

${ }^{36}$ Chapra, Sistem ..., h. 137.

${ }^{37}$ M. Umer Chapra, Al-Qur'an ..., h. 16.

${ }^{38}$ Ibid, h. 17.

${ }^{39}$ Ibid, h. 20.

\section{Daftar Pustaka}

Al-Masri, Rafiq. Inflation and It's Impaction Societies - The Islamic Solution. A paper submitted in the second workshop. Kuala lumpur: 1996.

An-Nababan, M. Faruq. 2000. Sistem Ekonomi Islam: Pilihan Setlah Kegagalan Sistem Kapitalis dna Sosialis. Yogyakarta: UII Pers.

Collins. 1997. Kamus Lengkap Ekonomi Terjemahan Tumpul Rumapea dan Posman Haloho. Jakarta: Airlangga, 1994 Chapra, M. Umer. Al-Qur'an Menuju Sistem Moneter yang Adil Terjemahan Lukman Hakim. Yogyakarta: Dana Bhakti Prima Yasa.

Chapra, M. Umer. 2002. Islam dan Tantangan Ekonomi. Jakarta: Gip dan Tazkia. 
Muhammad Ridha: Inflasi Berdasarkan Pandangan M. Umer Chapra 135 2008. Reformasi Ekonomi Sebuah Solusi Perspektif Islam

Terjemahan Ikhwan Abidin Basri, MA. Jakarta: Bumi Aksara. 2002. Sistem Moneter Islam Terjemahan Ikhwan Abidin Basri, MA.

Jakarta: Gema Insani Press. 2005. Islam dan Pembangunan Ekonomi Terjemahan Ikhwan Abidin

Basri, MA. Jakarta: Gema Insani Press. 2000. Islam dan Tantangan Ekonomi Terjemahan Ikhwan Abidin

Basri, MA. Jakarta: Gema Insani Press.

. 2001. Masa Depan dan Ilmu Ekonomi Sebuah Tinjauan Islam

Terjemahan Ikhwan Abidin Basri, MA. Jakarta: Gema Insani Press. . 1985. Towards a Just Monetary System. London: The Islamic

Foundation

Huda, Nurul et.al. 2008. Ekonomi Makro Islam. Jakarta: Kencana.

Islamy, M. Irfan. 2013. Prinsip-Prinsip Perumusan Kebijaksanaan Negara. Jakarta: Airlangga.

Karim, Adiwarman. 2007. Ekonomi Makro Islam. Jakarta: Raja Grafindo Persada.

Moleong, Lexy J. 2000. Metodologi Penelitian Kualitatif. Bandung: Remaja, Rosdakarya.

Mufraini, M. Arif. 2013. Metodologi Penelitian Bidang Studi Ekonomi Islam. Jakarta: UIN Jakarta Press.

Nasution, Mustafa Edwin, et.al. 2006. Pengenalan Eksklusif Ekonomi Islam. Jakarta: Kencana.

Natsir, M. 2014. Ekonomi Moneter dan Kebanksentralan. Jakarta: Mitra Wacana Media.

Nazori, Majid M. 2003. Pemikiran Ekonomi Islam Abu Yusuf Relavansinya dengan Ekonomi Kekinian, Yogyakarta: PSEI.

http://www.bi.go.id/id/moneter/inflasi/pengenalan/contents/Default.aspx diakses pada tanggal 20 September 2018

P3EI, Pusat Pengakajian dan Pengembangan Ekonomi Islam. 2011. Ekonomi Islam. Jakarta: Raja Grafindo Persada.

Rofiq, Ahmad S. 2002. Fiqh Aktual: Sebuah Ikhtiar Menjawab Berbagai Persoalan Umat. Semarang: Putra Mediatama Press. 
Simorangkir, Iskandar. 2014. Pengantar Kebanksentralan: Teori dan Praktik di Indonesia. Jakarta: Rajawali Pers.

Sukirno, Sadono. 2010. Pengantar Teori Makro Ekonomi. Jakarta: Raja Grafindo Persada.

Suprayitno, Eko. 2005. Ekonomi Islam Pendekatan Ekonomi Makro Islam dan Konvensional. Yogyakarta: Graha Ilmu.

Wahab, Solichin Abdul. 2005. Analisis Kebijaksanaan dari Reformulasi ke Implementasi Kebijaksanaan Negara. Jakarta: Bumi Aksara.

Winardi. 2005. Kamus (Inggris-Indonesia). Bandung: Alumni. 